\title{
Human oral cells' response to different endodontic restorative materials: an in vitro study
}

\author{
Susanne Jung*, Jana Mielert, Johannes Kleinheinz and Till Dammaschke
}

\begin{abstract}
Introduction: The aim of this study was to compare the biological interaction of human osteoblasts and cells of the human periodontal ligament (PDL) with different endodontic restorative material as Mineral Trioxide Aggregate (MTA), Biodentine, amalgam and composite over a time period of 20 days.

Materials and methods: Human PDL cells and osteoblasts were harvested, cultured and according to standardized protocols. The cell populations were characterized with the corresponding surface markers following standardized procedures. The specimens were produced with special regard to constant dimensions and volume in the different groups. Cell attachment and proliferation were evaluated morphologically after Richardson staining and cell count was performed after $1 d, 8 d, 13 d$ and $20 d$. All experiments were performed in triplets. The results were statistically analyzed using the ANOVA- and Tukey-test $(p<0.05)$.
\end{abstract}

Results: Morphological analysis proved good proliferation and cell attachment in both cements. A remarkable result was the organized spreading and parallel alignment of the PDL cells in contact with MTA and especially Biodentine (cells maturing in a second cell layer crossway to the first one). From $8 \mathrm{~d}$ onward Biodentine showed the highest quantity of PDL cells $(p<0.05)$. Biodentine and MTA resulted in a significantly higher cell density in osteoblast and PDL cell culture. The other groups showed a lower PDL cell density from $8 \mathrm{~d}$ and a lower osteoblast cell density from 13d when compared to control and cement samples $(p<0.05)$.

Conclusions: MTA and Biodentine showed a good biocompatibility in contact with the human osteoblasts and cells of the periodontal ligament. Regarding cell survival and proliferation particularly of PDL cells Biodentine showed good results and can be considered as a well-tolerated bioactive endodontic material.

Keywords: Amalgam, Biodentine, Composite resin, Mineral Trioxide Aggregate, Osteoblasts, Periodontal ligament cells

\section{Introduction}

During endodontic therapy a perforation of the root canal system may occur or a root-end surgery may be necessary. Both procedures resulting in communication of the pulp chamber or the root canal system with the periodontium. For the best prognosis, these contact areas must be restored and sealed. Hence, aim of such filling is to obturate the root-end or perforation cavity and to prevent micro leakage. A suitable filling material should:

\footnotetext{
* Correspondence: Susanne.Jung@ukmuenster.de

Department of Maxillofacial Surgery, Albert-Schweitzer-Campus 1, Building W30, 48149 Münster, Germany
}

- be biocompatible;

- ensure a long-term three-dimensional sealing of all margins, preferably by a molecular bonding to the dentinal walls;

- be bacteriostatic, or not encourage bacterial growth;

- be stable;

- be insoluble;

- be non-absorbable;

- be not moisture-sensitive;

- be easy to prepare and place;

- be radiopaque and

- be bioactive and induce regeneration of the periodontal ligament and bone [1-4].

Nevertheless, for a successful endodontic therapy a high quality apical root canal filling or perforation repair 
is essential. In the past, numerous different materials like amalgam, reinforced zinc oxide eugenol cements (IRM, Super-EBA), glass ionomer cement, and composite resin were used to fill endodontic perforations or as root-end filling material $[2,4-10]$. Unfortunately, an ideal root-end filling material has yet not been found $[2,4]$.

In the recent years Mineral Trioxide Aggregate (MTA), a refined Portland cement $[11,12]$, was extensively tested for this propose and was found to provides distinctly less cytotoxic effects and better results concerning material properties, biocompatibility, microleakage protection, bioactivity and thus, clinical success than traditional materials recommended for root-end fillings or perforation repair. Due to its good biocompatibility, mechanical stability and regenerative impact on hard tissue and periodontium, ProRoot MTA is denoted as a reference material for root perforation repair and root-end obturation [13-15].

Even though ProRoot MTA (Dentsply/Tulsa, Tulsa, OK, USA) appears to be the preferred material in the above mentioned indications with many positive features, the cement does have several drawbacks: the handling can be difficult, the setting time is long, the use in the visible crown area may lead to tooth discoloration, the compressive and flexural strength is lower than dentine and it is quite expensive [4,16-18].

Recently, a new bioactive calcium silicate cement, Biodentine (Septodont, St. Maur-des-Fossés, France), was launched on the dental market. Biodentine consists of a powder in a capsule and liquid in a pipette. According to Camilleri et al. the powder consists mainly of $\mathrm{SiO}_{2}$ (16.90\%), $\mathrm{CaO}$ (62.9\%), $\mathrm{ZrO}_{2}$ (5.47\%), and the liquid is composed of $\mathrm{Na}(15.8 \%), \mathrm{Mg}$ (5.0\%), $\mathrm{Cl}(34.7 \%), \mathrm{Ca}(23.6 \%)$, and $\mathrm{H}_{2} \mathrm{O}(20.9 \%)$ [19].

Compared to ProRoot MTA until now comparatively little information about Biodentine is available. Used as root-end filling Biodentine showed clinically a good bony regeneration after apicoectomy [20]. When comparing its material characteristics to established tricalcium silicate cements Biodentine stands out by its greater compressive strength, most likely caused by the low water/ cement ration of the mixture. The material is described less porous and denser than MTA; the alkaline $\mathrm{pH}$ of Biodentine is comparable to other cements. Investigations of the microleakage revealed that tracer diffusion between dental material and dentin walls was significantly reduced in Biodentine samples compared to glass ionomer cement and MTA. The colour stability of Biodentine allows its appliance in aesthetically susceptible areas [21].

Nevertheless, the selection of a repair material is critical because biocompatibility and sealing ability are reported to have an effect on the prognosis of perforation closure or apicoectomy [22]. The biocompatibility of endodontic materials is essential because during application the materials/cements might get direct contact to the surrounding bone or the periodontium for a prolonged period of time. Periodontal ligament (PDL) fibroblasts with specialized functions are responsible for the formation and maintenance of PDL fibre attachments as well as repair, remodelling, and regeneration of the adjacent alveolar bone and cementum [23]. PDL cells are responsible for normal maintenance and regeneration of the PDL [24]. In addition to PDL fibroblasts, cells from the surrounding alveolar bone are likely to play an important role in the repair and regeneration of periradicular tissue [25]. PDL cells are usually formed around the rootend or perforation filling materials [26]. Osteoblasts and PDL cells are the principal cells responsible for osseous excisional wound healing after periradicular surgery [27].

Thus, the aim of this investigation was to analyze the biological interaction of human osteoblasts, and cells of the PDL with different endodontic restorative materials: Mineral Trioxide Aggregate cement (ProRoot MTA), Biodentine (as another calcium silicate cement), amalgam, and composite resin up to 20 days in vitro. Amalgam and composite were included in the study design to analyze their biological effects on cells in direct proximity to further clarify their influence on cell proliferation in an in vitro setting.

The null-hypotheses of this study were that Biodentine will show biocompatible reaction to PDL cells and osteoblasts comparable to ProRoot MTA, whereas amalgam and composite resin will have a negative impact.

\section{Materials and methods \\ Sample preparation}

The following materials were included in this study: ProRoot MTA (Dentsply/Tulsa, Tulsa, OK, USA), Biodentine as other calcium silicate cement (Septodont, Saint-Maur-des-Fossés, France), a light-curing composite resin (Estelite $\Sigma$ Quick; Tokuyama Dental, Tokyo, Japan) and an amalgam (Oralloy Magicap S; Coltène/Whaledent, Altstätten, Switzerland).

From all materials samples were produced with a defined diameter of $5 \mathrm{~mm}$ and a height of $2 \mathrm{~mm}$. All materials were handled strictly according to manufacturer recommendations. The samples were prepared with consideration of their specific curing processes: while Biodentine sets for 12 minutes, MTA sets for four hours and amalgam for 24 hours. The composite samples were light cured in layers (incremental technique).

The human cells were harvested and cultured according to a standardized protocol. All cell samples were taken after the patients' informed consent. The Ethics committee of the Westphalian Wilhelms-University, Münster, Germany approved the use of human cells (Reg. No. 1IXKlei1). The handling of all human samples followed strictly the "Declaration of Helsinki". 
Primary osteoblasts were harvested from bone chips collected during modelling mandibular osteotomies or the surgical removal of lower wisdom teeth. The bone particles were cultured in MMO medium (High Growth Enhancement Medium; MP Biomedicals, Eschwege Germany) with fetal bovine serum, Penicillin $(10.000 \mathrm{U} / \mathrm{ml})$, Streptomycin $(10.000 \mu \mathrm{g} / \mathrm{ml})$ and Amphotericin B $250 \mu \mathrm{g} / \mathrm{ml}$ (Biochrom, Berlin, Germany). After 10 days dexamethasone (Merck, Darmstadt, Germany; 0.02\% in phosphate buffered saline (PBS Dulbecco, Biochrom, Berlin, Germany) was added to the medium.

The outgrowing cells were characterized immunohistochemically by positive expression of osteocalcin, osteonectin and collagen I. The second passage was used for the experiments.

The human periodontal ligaments cells were harvested from the periodontal membrane of impacted, surgically removed wisdom teeth, which therefore did not have any contact with the oral cavity at any time. The PDL cells were cultured in Dulbeco's Modified Eagle Medium $1 X$ (Lot 1012067, 4,5 g/l Glucose, L-Glutamine, Pyruvate; gibco by life technologies, Darmstadt, Germany) with fetal bovine serum, Penicillin $(10.000 \mathrm{U} / \mathrm{ml})$, Streptomycin $(10.000 \mu \mathrm{g} / \mathrm{ml})$ and Amphotericin B $250 \mu \mathrm{g} / \mathrm{ml}$ (Biochrom, Berlin, Germany).

The material samples were placed in 6-well-dishes (TPP, Trasadingen, Switzerland) and brought in direct contact to the harvested cell. The cells were plated at a density of 5,000 cells $/ \mathrm{cm}^{2}$ and cultured in their respective cell culture medium (PDL cells in Dulbeco's Modified Eagle Medium 1X and osteoblasts in MM0, High Growth Enhancement Medium with dexamethasone and in the presence of the samples. Cells at passage P2 were used for the study. All experiments were performed in triplets. The in-vitro investigations were performed after defined intervals of one, eight, thirteen and twenty days. To control the growth and proliferation of the cells also cultures without contact to any test material were assessed (control group).

\section{Morphological analysis}

For histological evaluation the cell cultures were fixed in methyl alcohol (Merck, Darmstadt, Germany) at $21^{\circ} \mathrm{C}$ room temperature, air dried and a Richardson staining was performed. The Richardson solution ready for use consisted of two filtered stock solutions. Stock solution I is $1 \%$ methylen blue in $1 \%$ sodium borate. The stock solution II is a solution of $1 \%$ azure in distilled water (Merck, Darmstadt, Germany). The working solution is prepared on day of use by mixing the stocks 1:1 and stored in a syringe with a $22 \mu \mathrm{m}$ filter. For the dyeing of the cell cultures the working solution was warmed to $60^{\circ} \mathrm{C}$, two drops of the solution were given to every deepening and the slides were stained for one minute.
They were subsequently washed in bidistilled water, air dried and mounted. With the help of light microscopic images of the cell cultures in the Richardson's stain the morphology and proliferation of the cells were evaluated.

\section{Cell count}

After siphoning the culture medium, the samples were washed twice with PBS, covered with a thin film of $1 \mathrm{ml}$ trypsin (0.05\%)/EDTA (0.02\%) solution (Biochrom, Berlin, Germany) and incubated in the incubator for three minutes. The reaction was stopped by admixing $2 \mathrm{ml}$ of the fresh corresponding medium and the cells were resuspended by thoroughly pipetting up and down several times.

$100 \mu \mathrm{l}$ of the cell suspension of each deepening was pipetted into a Coulter-potty (Beckman Coulter $\mathrm{GmbH}$, Krefeld, Germany) filled with $10 \mathrm{ml}$ isotone electrolyte solution (CasyTon; Schärfe System, Reutlingen, Germany). A cell count was performed with the Casy 1 Cell Counter \& Analyzer system (Schärfe System, Reutlingen, Germany).

The proliferation of the osteoblasts and the PDL cells was considered and evaluated referring to the determined absolute cell counts in the presence of the four materials as well as in their absence. The cell colonies were assessed based on the morphological analysis of the cell size, the morphology of the nucleus and the proliferation. All results were statistically analyzed using the ANOVA and Tukey test $(\mathrm{p}<0.05)$.

\section{Results}

\section{Morphological analysis}

\section{Osteoblasts}

When analyzing the morphology under human osteoblasts' interaction with ProRoot MTA, Biodentine and amalgam as well as with the control group, the histological imaging was homogenous. An increasing density of the cells was observed for all cell cultures in the presence of these materials. At the same time, an increasing number of polygonal cells were noticed (Figure 1a-c, e). The cell reactions to the presence of polymerized composite resin were in strong contrast to these results: the histological images illustrated structural decomposition up to numerous cell losses (Figure 1d).

\section{PDL cells}

During the first days of cell culture, the PDL cells appeared as long, slender cells without an ordered arrangement. The cells were similar to fibroblasts. In addition to that, polygonal cells could occasionally be identified. In the further course of the cultivation a remarkably strong growth of the cultures took place so that after twenty days a confluent monolayer could be recognized 


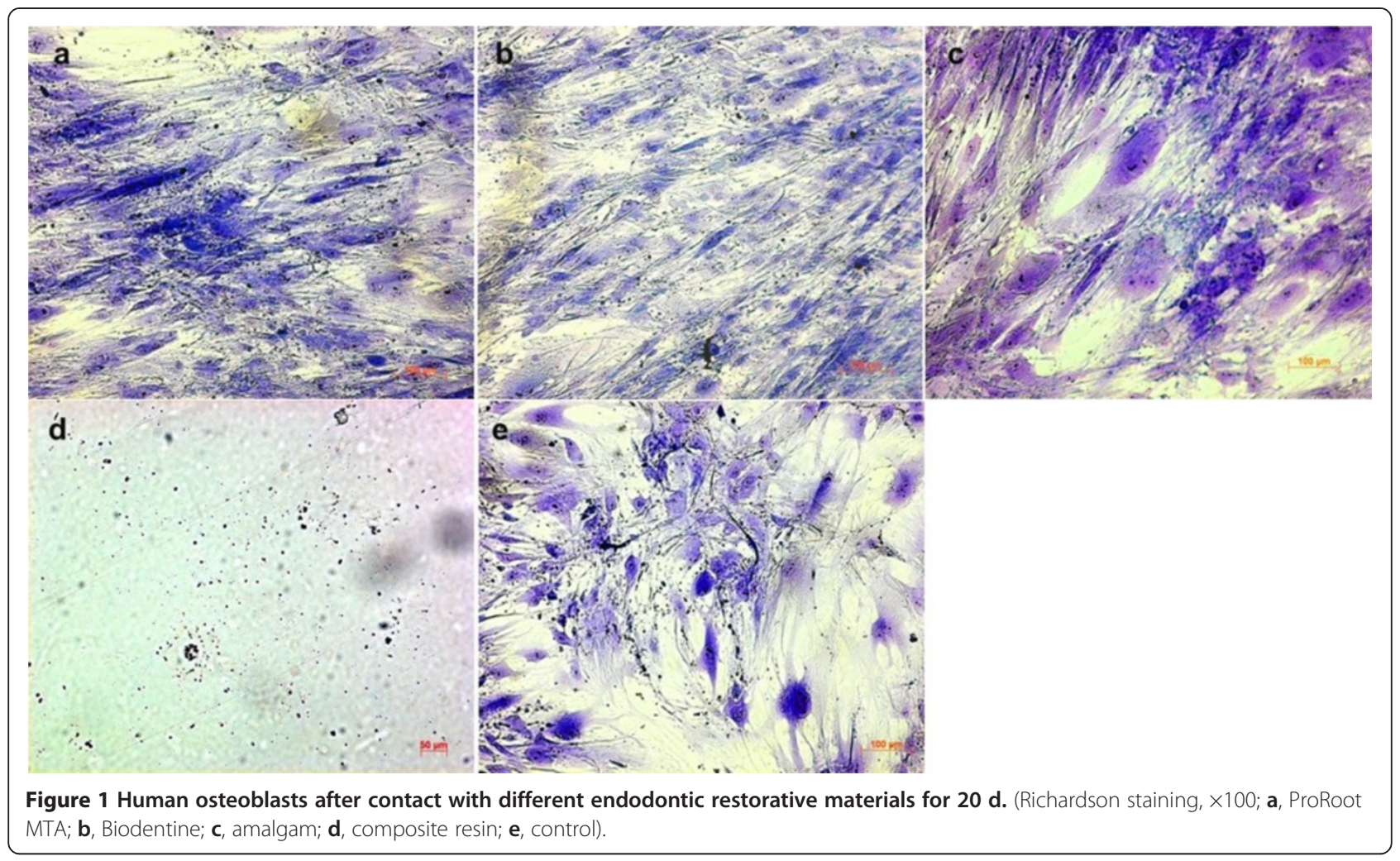

in all cultures. An exceptional result was the organized spreading and the strictly parallel alignment of the cells (Figure 2a-e). The presence of Biodentine had impressive stimulatory effects. Only in this group beyond the forming of a confluent cell layer, the PDL cells matured in a second cell layer crossway to the first one (Figure 2b). In contrast the culture under the influence of the polymerized composite resin showed reduced cell density and growth. An increase of cells had occurred and they ordered themselves in a parallel arrangement, but no confluent monolayer was formed after $20 \mathrm{~d}$ (Figure 2d).

\section{Cell count}

\section{Osteoblasts}

One day after the application of the human osteoblasts onto the material samples the cell quantity was significantly decreased in all groups compared to the untreated control group $(p<0.05)$. In the following days it became obvious that the light cured composite resin samples had a negative impact on the osteoblasts. The number of cells dropped considerably. In all other groups the amount of cell increased within one week. After that time the Biodentine group showed significantly more osteoblasts than all other group $(\mathrm{p}<0.05)$, whereas after $13 \mathrm{~d}$ significantly more cells could be detected in the ProRoot MTA group $(\mathrm{p}<0.05)$. After $20 \mathrm{~d}$ a slight reduction in the cell amount was visible in all groups.
However, Biodentine and ProRoot MTA showed significantly more cells than all other groups. Already after $8 \mathrm{~d}$ Biodentine showed a significant higher quantity of cells compared to the control group, whereas in the amalgam group the amount of cells was significant lower compared to the control group at all days $(\mathrm{p}<0.05)$ (Figure 3).

\section{PDL cells}

The application of the material samples to PDL cells had not that impact on the cell quantity than it has on the osteoblasts after one day. In the amalgam and in the ProRoot MTA group the cell quantity was statistically not significantly different from the control group $(\mathrm{p}>0.05)$. Comparable to the osteoblast culture the composite resin showed a strong negative effect on PDL cells $(\mathrm{p}<0.05)$. Thus, the amount of cells dropped considerably. Also comparable to the osteoblasts the amount of PDL cells clearly increased in all other groups after one day. Nevertheless, after $8 \mathrm{~d}$ and $20 \mathrm{~d}$ in contact with amalgam and ProRoot MTA the amount of cells was significantly lower compared to the control group $(\mathrm{p}<0.05)$ whereas from 8 $\mathrm{d}$ onward Biodentine showed a significantly higher quantity of PDL cells compared to all other groups $(\mathrm{p}<0.05)$. After $13 \mathrm{~d}$ a difference in the cell number could not be detected between the controls and ProRoot MTA $(p>0.05)$ (Figure 4). 


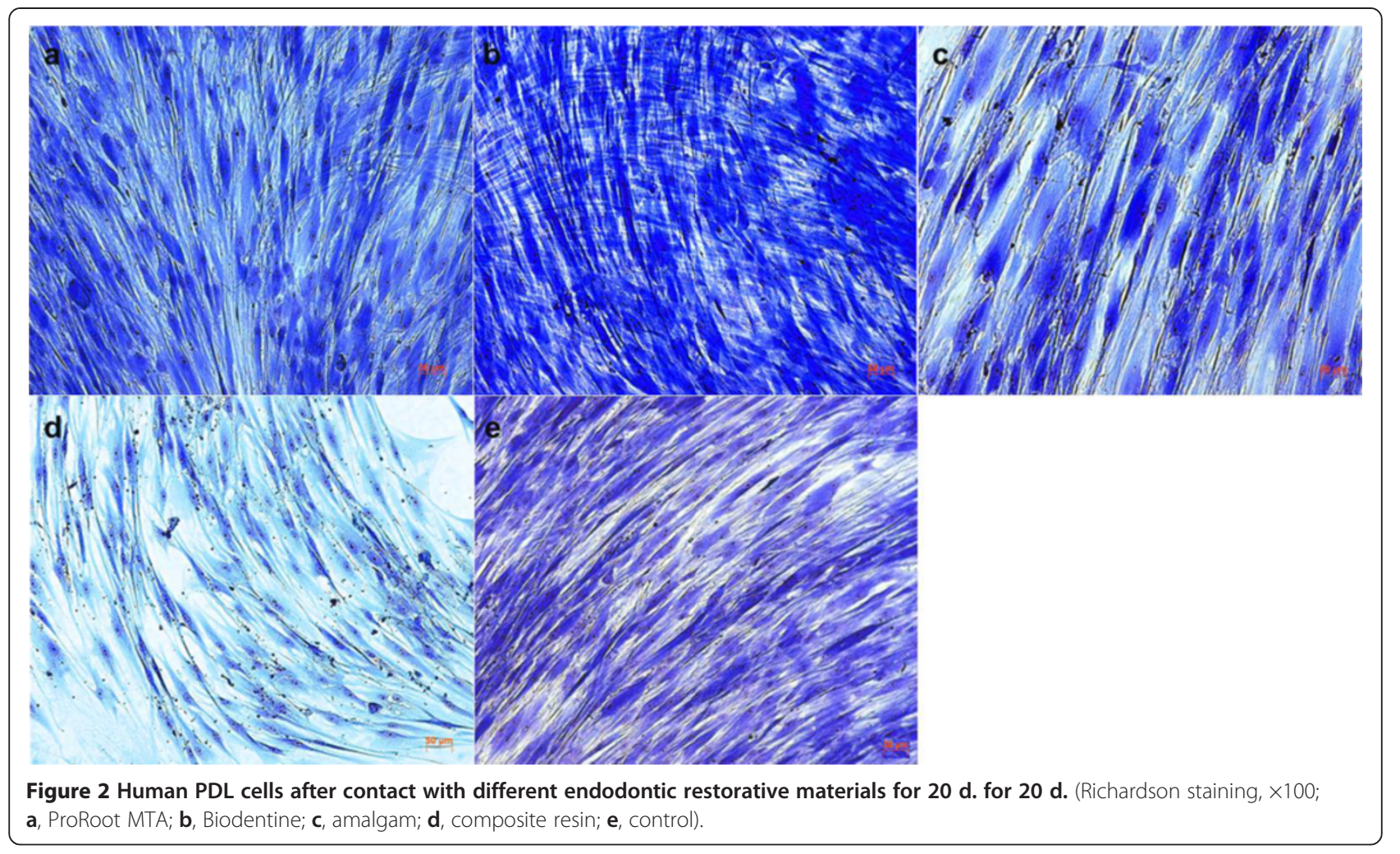

\section{Discussion}

The most ideal healing outcome after filling the resected root canal or the perforation would be reformation of a normal attachment apparatus with healthy bone, periodontal ligament, and cementum [27]. Hence, the ultimate goal of treatment of root perforations or root-end surgery is to maintain or re-establish the damaged attachment apparatus [28]. Damage of the PDL will have adverse effects on healing following endodontic surgery, bony regeneration and may lead to an unfavourable outcome of treatment. Hence, to evaluate the biocompatibility and bioactivity of a new calcium silicate cement (Biodentine) in comparison to ProRoot MTA human osteoblasts and PDL cells were chosen for this ex vivo study. The results from studies of these cells are favourable to those from other cell lines (e.g. osteosarcoma cells) or cells of animal origin because their reaction concerning cell attachment and mineralization may be different to human osteoblasts or PDL cells [24,25].

In the resent years MTA has been extensively examined in dental science and numerous cytotoxicity and cell attachment investigations with various cell cultures showed better results with MTA in comparison to very many other dental materials [14]. Nowadays, the use of MTA can be assumed as gold standard for the closure of perforations defects or as root-end filling against which other materials need to be tested. The very good biocompatibility and bioactivity of MTA on PDL cells and osteoblasts are confirmed in the present study and are in fully accordance with the present knowledge about MTA [13-15].

Whereas MTA is very well investigated also on human cell lines [14] to the best of our knowledge until today no data are published concerning the effect of Biodentine to human osteoblasts or PDL cells. Only Zhou et al. compared Biodentine and MTA in direct contact on human gingival fibroblasts. Both cements showed no significant differences in cell viabilities. The cells attached to and spread over both material surfaces [29].

When comparing Biodentine and its characteristic properties to other well established dental materials as Super EBA or glass ionomer cement one has no recourse to much experimental data in current literature. In an investigation of $2012 \mathrm{Al}$-Hiyasat et al. observed the quality of cellular attachment to various root-end filling materials and concluded that the best cellular attachment of fibroblasts can be observed on the surface of MTA, whereas Super EBA surfaces did not attract cell adherence most likely due to the leaking of eugenol into the dentinal tubules. Unwashed glass ionomer cement surfaces did not induce cell attachment either [30]; these findings support our data concerning the biological effect of MTA. In a direct comparison of Biodentine and glass ionomer cement as dentine replacement material by Camilleri in 2013, glass ionomer cements showed more physical and chemical stability and led to significantly less microleakage 


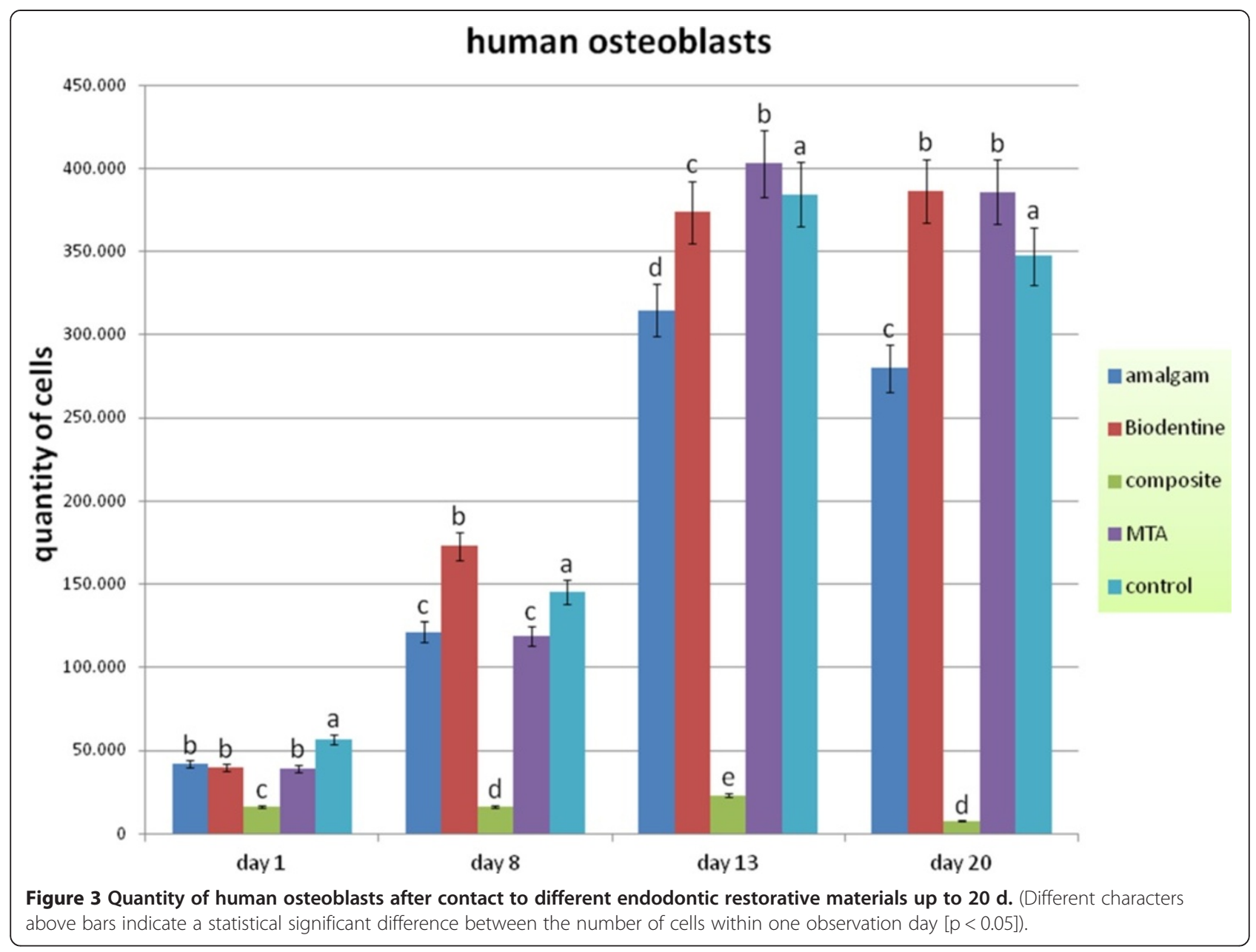

when applied under composite restorations in a sandwich technique. The indication and application for each material have to be well considered [31].

The results of the present study emphasize that Biodentine - beside MTA - can be called a bioactive cement by up-regulating osteoblasts and PDL cells activity. Biodentine can be considered as a material that may induce periodontal regeneration and/or repair. Biodentine has favourable properties regarding biologic response of the cells within the periodontium which were evaluated in this study. Only in contact to Biodentine the PDL cells matured in a second cell layer crossway to the first one. And from $8 \mathrm{~d}$ onward Biodentine showed the statistically significant highest quantity of PDL cells.

Biodentine is mainly composed out of tri- and dicalcium silicate. Recent research in medicine clearly showed that the addition of tricalcium silicate to calcium phosphate bone cements improves the bioactivity of those materials on osteoblast or osteoblast like cells [32,33]. This may be related to the release of silicon ( $\mathrm{Si})$ from calcium silicate cements. It is well known that $\mathrm{Si}$ has a positive impact on bone metabolism and enhances the rate of new bone growth when released from bioactive materials in vivo [34-36]. These findings suggest that the release of $\mathrm{Si}$ from calcium silicate cements may confer additional in vivo bioactivity of these materials.

Furthermore, Biodentine and MTA are able to develop a hydroxyl apatite-like surface in the presence of body liquids containing calcium or phosphate [37]. This surface is biocompatible and displays good conditions for cell attachment and proliferation [37,38]. Biodentine showed significantly higher levels of calcium and silicon ion release than MTA [38-40]. Hence, it may be speculated in how far the higher release of $\mathrm{Ca}$ and $\mathrm{Si}$ from Biodentine may explain the present findings.

For many years, amalgam was accepted as the material of choice in endodontic surgery but it came into question when concerns about its toxicity arose $[1,41,42]$. Hence, amalgam is far from being an ideal restorative material in endodontics as a consequence of its potential disadvantages: beside the potential biological toxicity of its constituents, initial leakage, moisture sensitivity, and need for an undercut in the cavity preparation are mentioned $[1,41,42]$. Thus, in vivo amalgam used as material 


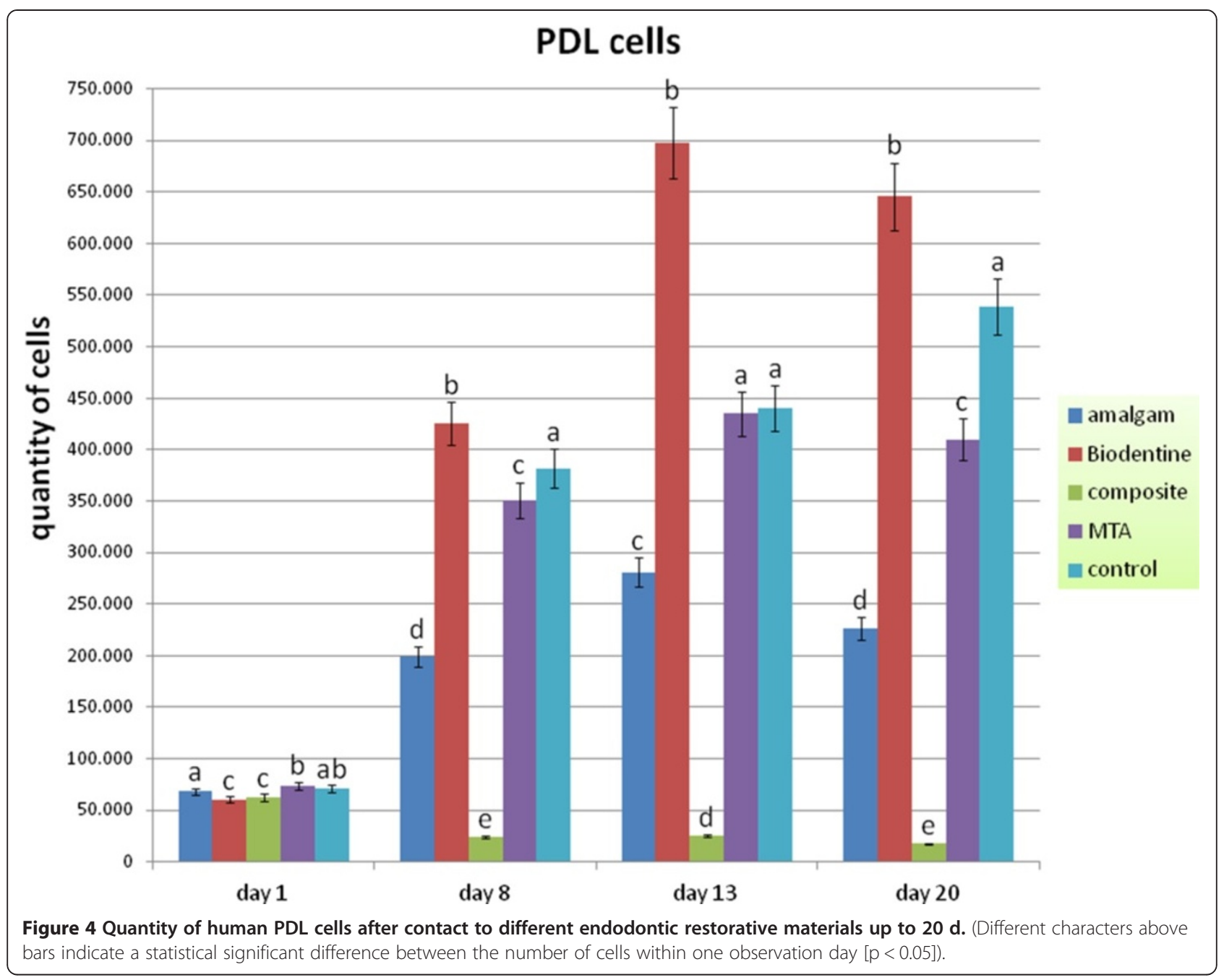

to repair furcation perforations leads to severe inflammatory response in the furcal bone [43]. In contact to PDL cells amalgam showed a mild [44] to severe [45] cytotoxicity showing early manifestation of cell injury [25]. Thus, Zhu et al. found a significantly lower total cell number of osteoblasts and PDL cells in direct contact to amalgam compared to the untreated control group after $3 \mathrm{~d}$ and $7 \mathrm{~d}$ [46].

Compared to MTA in direct contact to human PDL cells amalgam was significantly more cytotoxic within 1 $\mathrm{d}$ and the PDL cell density was lower after $4 \mathrm{~d}[47,48]$. After $72 \mathrm{~h}$ direct contact to amalgam the number of osteoblast-like cells was significantly lower than after contact to MTA. Whereas the number of the cells in the MTA group was significantly lower than that in the untreated control group [49].

The result of this study showed that the negative impact amalgam on human PDL cells and osteoblasts was not as distinct as hypothesized. Nevertheless, because the quantity of PDL cells and osteoblasts were significantly lower than in the control group at all days, amalgam showed no bioactivity and thus cannot be recommended as filling material in endodontic surgery.

Only limited reports about the influence of composite resins on cells associated with bone formation and periodontal repair are available [50]. Hence, ex vivo studies like the present are of some importance. It may be concluded from the results of the present study that the direct contact of PDL cells and osetoblasts to composite resin should be avoided because cell proliferation is suppressed.

Comparable to the present study Tai and Chang found that composite resin exhibited the most toxic effects followed by amalgam. Thus, amalgam reacts more favourable to PDL cells than composite resin [28].

In contrast to the present study Zhu et al. showed osteoblasts attached and spread on composite resin as well as on MTA by forming a monolayer [51] and cementum with inserting collagenous fibres from the periodontal ligament have been reported to form on composite resin 
in vivo [52]. Nevertheless, composite resin showed clearly cytotoxic effects on osteoblasts [53]. Thus, a variety of studies investigating cytotoxic effects of composite resin monomers on mammalian cells have demonstrated that unreacted resin monomers from rein-based materials can cause adverse biological effects on oral tissue. Hence, dental resin monomers showed genetic and cellular toxicology. Unpolymerized monomers released from cured composite resin may hamper the healing process of surrounding tissue. Thus, the usage of such materials in direct contact with bone, periapical or periodontal tissue is questionable [50,53-55].

In the present investigation the leachable components in the culture medium were not assessed. Nevertheless, cytotoxic monomers are eluted from light cured composite resin in a significant extent $[50,56]$.

The null-hypothesis of this investigation could not be fully confirmed: The effect of Biodentine on osteoblast was comparable to ProRoot MTA whereas quantity of PDL cells after contact to Biodentine was significantly higher compared to ProRoot MTA from day 8 onward. The quantity of human osteoblasts and PDL cells after contact to amalgam was significantly lower compared to the control but significantly higher compared to the composite resin. Thus, both materials had a negative impact to the tested cells, whereas the results in the composite group were significantly worse. Only in the composite resin group a remarkable structural changes up to numerous cell losses, reduced cell density and growth could be observed but no confluent monolayer.

\section{Conclusion}

ProRoot MTA and Biodentine showed no cytotoxicity and a good biocompatibility in direct contact with osteoblasts and PDL cells. Regarding cell survival and proliferation particularly of PDL cells Biodentine showed good results and can be considered as a well-tolerated endodontic material with stimulatory bioactive properties. Amalgam and especially composite resin might not provide an appropriate environment for osteoblasts and PDL cells.

\section{Competing interests}

The authors declare that they have no competing interests.

\section{Authors' contributions}

All authors have contributed significantly to this work and contributed to the paper in the equal parts: SJ had the idea for the research and developed the concept, participated in the experiments, literature research and writing of the manuscript. JM performed the in vitro experiments and participated in the literature research and writing of the manuscript. JK participated in literature research, writing of the manuscript and carried out proofreading. TD participated in study development, literature research, writing of the manuscript and carried out proofreading. All authors read and approved the final manuscript.

\section{Acknowledgement}

We acknowledge support by Deutsche Forschungsgemeinschaft and Open Access Publication Fund of University of Muenster, Germany.
Received: 18 July 2014 Accepted: 5 December 2014

Published online: 23 December 2014

\section{References}

1. Gartner AH, Dorn SO: Advances in endodontic surgery. Dent Clin North Am 1992, 36:357-378.

2. Carr GB: Surgical endodontics. In Pathways of the pulp. 6th edition. Edited by Cohen S, Burns RC. St. Louis: Mosby; 1994:531-567.

3. Pitt Ford TR: Surgical treatment of apical periodontitis. In Essential endodontology. Edited by Ørstavik D, Pitt Ford TR. Oxford: Blackwell; 2003:278-308.

4. Stropko JJ: Micro-surgical endodontics. In Endodontics Vol III. Edited by Castellucci A. Florence: Edizioni Odontoiatriche II Tridente; 2009:1118-1125.

5. EIDeeb ME, EIDeeb M, Tabibi A, Jensen JR: An evaluation of the use of amalgam, cavit and calcium hydroxide in the repair of furcation perforations. J Endod 1982, 8:456-466.

6. Gutmann JL, Harrison JW: Surgical endodontics. Boston: Blackwell; 1991:203-277.

7. Rud J, Rud V, Munksgaard EC: Long-term evaluation of retrograde root-filling with dentine-bonded resin composite. J Endod 1996, 22:90-93.

8. Rud J, Rud V, Munksgaard EC: Retrograde sealing of accidental root perforations with dentin-bonded resin composite. J Endod 1998, 24:671-677.

9. Rud J, Rud V, Munksgaard EC: Periapical healing of mandibular molars after root-end sealing with dentin-bonded resin composite. Int Endod J 2001, 34:285-292.

10. Bodrumlu E: Biocompatibility of retrograde root filling materials: $A$ review. Aust Endod J 2008, 34:30-35.

11. Camilleri J, Montesin FE, Brady K, Sweeney R, Curtis RV, Pitt Ford TR: The constitution of mineral trioxide aggregate. Dent Mater 2005, 21:297-303.

12. Dammaschke T, Gerth HUV, Züchner H, Schäfer E: Chemical and physical surface and bulk material characterization of white ProRoot MTA and two Portland cements. Dent Mater 2005, 21:731-738.

13. Parirokh $M$, Torabinejad M: Mineral trioxide aggregate: a comprehensive literature review - Part l: chemical, physical, and antibacterial properties. J Endod 2010, 36:16-27.

14. Torabinejad M, Parirokh M: Mineral trioxide aggregate: a comprehensive literature review - Part II: leakage and biocompatibility investigations. J Endod 2010, 36:190-202.

15. Parirokh M, Torabinejad M: Mineral trioxide aggregate: a comprehensive literature review - Part III: Clinical applications, drawbacks, and mechanism of action. J Endod 2010, 36:400-413.

16. Karabucak B, Li D, Lim J, lqbal M: Vital pulp therapy with mineral trioxide aggregate. Dent Traumatol 2005, 21:240-243.

17. Belobrov I, Parashos P: Treatment of tooth discoloration after the use of white mineral trioxide aggregate. J Endod 2011, 37:1017-1020.

18. Dammaschke T: Direct pulp capping. Dentist 2011, 27:88-94.

19. Camilleri J, Kralj P, Veber M, Sinagra E: Characterization and analyses of acid-extractable and leached trace elements in dental cements. Int Endod J 2012, 45:737-743.

20. Dammaschke T: Root-end filling with a new bioactive cement. Inside Dent 2012, 8:86-88

21. Rajasekharan S, Martens LC, Cauwels RGEC, Verbeeck RMH: Biodentine ${ }^{\text {TM }}$ material characteristics and clinical applications: a review of the literature. Eur Arch Paediatr Dent 2014, 15:147-158.

22. Dazey S, Senia ES: An in vitro comparison of the sealing ability of materials placed in lateral root perforations. J Endod 1990, 16:19-23.

23. Boyko GA, Melcher AH, Brunette DM: Formation of new periodontal ligament by periodontal ligament cells implanted in vivo after culture in vitro. A preliminary study of transplanted roots in the dog. J Periodontal Res 1981, 16:73-88.

24. Mariotti A, Cochran DL: Characterization of fibroblasts derived from human periodontal ligament and gingiva. J Periodontol 1990, 61:103-111.

25. Al-Rabeah E, Perinpanayagam $\mathrm{H}$, MacFarland D: Human alveolar bone cells interacts with ProRoot and tooth-colored MTA. J Endod 2006, 32:872-875.

26. Balto H, Al-Nazhan S: Attachment of human periodontal ligament fibroblasts to 3 different root-end filling materials: Scanning electron microscope observation. Oral Surg Oral Med Oral Pathol Oral Radiol Endod 2003, 95:222-227. 
27. Harrison JW, Jurosky KA: Wound healing in the tissues of the periodontium following periradicular surgery. III. The osseous excisional wound. J Endod 1992, 18:76-81.

28. Camp MA, Jeansonne BG, Lallier T: Adhesion of human fibroblasts to root-end-filling materials. J Endod 2003, 29:602-607.

29. Tai KW, Chang YC: Cytotoxicity evaluation of perforation repair materials on human periodontal ligament cells in vitro. J Endod 2000, 26:395-397.

30. Al-Hiyasat AS, Al-Sa'Eed OR, Darmani $\mathrm{H}$ : Quality of cellular attachment to various root-end filling materials. J App/ Oral Sci 2012, 20:82-88.

31. Camilleri J: Investigation of Biodentine as dentine replacement material. J Dent 2013, 41:600-610.

32. Cytotoxicity evaluation of a novel root repair material. J Endod 2013, 39:478-483.

33. Zhao Q, Qian J, Zhou H, Yuan Y, Mao Y, Liu C: In vitro osteoblast-like and endothelial cells' response to calcium silicate / calcium phosphate cement. Biomed Mater 2010, 5:1-9.

34. Morejón-Alonso L, Ferreira OJB, Carrodeguas RG, dos Santos LA: Bioactive composite bone cement based on a-tricalcium phosphate/tricalcium silicate. J Biomed Mater Res B 2012, 100B:94-102.

35. Carlisle EM: Silicon: a possible factor in bone calcification. Science 1970, 167:279-280

36. Schwarz K, Milne DB: Growth-promoting effects of silicon in rats. Nature 1972, 239:333-334.

37. Patel N, Best SM, Bonfield M, Gibson IR, Hing KA, Damien E, Revell PA: A comparative study on the in vivo behavior of hydroxyapatite and silicon substituted hydroxyapatite granules. J Mater Sci Mater Med 2002, 13:1199-1206.

38. Gandolfi MG, van Lunduyt K, Taddei P, Modena E, van Meerbeek B, Prati C: Environmental scanning electron microscopy connected with energy dispersive X-ray analysis and Raman techniques to study ProRoot Mineral Trioxide Aggregate and calcium silicate cements in wet conditions and in real time. J Endod 2010, 36:851-857.

39. Han L, Okiji T: Uptake of calcium and silicon released from calcium silicate-based endodontic materials into root canal dentine. Int Endod J 2011, 44:1081-1087.

40. Han L, Okiji T: Bioactivity evaluation of three calcium silicate-based endodontic materials. Int Endod J 2013, 46:808-814.

41. Grech L, Mallia B, Camilleri J: Characterization of set Intermediate Restorative Material, Biodentine, Bioaggregate and prototype calcium silicate cement for use as root-end filling materials. Int Endod J 2013, 46:632-641.

42. Dorn SO, Gartner AH: Retrograde filling materials: a retrospective success-failure study of amalgam, EBA, and IRM. J Endod 1990, 16:391-393.

43. Torabinejad M, Watson TF, Pitt Ford TR: Sealing ability of a mineral trioxide aggregate when used as a root end filling material. J Endod 1993, 19:591-595.

44. Rafter M, Baker M, Alves M, Daniels J, Remeikis N: Evaluation of healing with use of an internal matrix to repair furcation perforations. Int Endod J 2002, 35:775-783.

45. Lin $C P$, Chen $Y J$, Lee $Y L$, Wang JS, Chang MC, Lan WH, Chang HH, Chao WMW, Tai TF, Lee MY, Lin BR, Jeng JH: Effects of root-end filling materials and eugenol on mitochondrial dehydrogenase activity and cytotoxicity to human periodontal ligament fibroblasts. Biomed Mater Res B Appl Biomater 2004, 71B:429-440.

46. Osorio RM, Hefti A, Vertucci FJ, Shawley AL: Cytotoxicity of endodontic materials. J Endod 1998, 24:91-96.

47. Zhu Q, Safavi KE, Spångberg LSW: Cytotoxic evaluation of root-end filling materials in cultures of human osteoblast-like cells and periodontal ligament cells. J Endod 1999, 25:410-412.

48. Keiser K, Johnson CC, Tipton DA: Cytotoxicity of mineral trioxide aggregate using human periodontal ligament fibroblasts. J Endod 2000, 26:288-291.

49. Hakki SS, Bozkurt SB, Ozcopur B, Purali N, Belli S: Periodontal ligament fibroblast response to root perforation restored with different materials - a laboratory study. Int End J 2012, 45:240-248.

50. Pelliccioni GA, Ciapetti G, Cenni E, Granhi D, Nanni M, Pagani S, Giunti A: Evaluation of osteoblast-like cell response to ProRoot MTA (mineral trioxide aggregate) cement. J Mater Sci Mater Med 2004, 15:167-173.
51. Imazato S, Horikawa D, Nishida M, Ebisu S: Effects of monomers eluted from dental resin restoratives on osteoblast-like cells. J Biomed Mater Res B Appl Biomater 2009, 88B:378-386.

52. Zhu Q, Haglund R, Safavi KE, Spångberg LSW: Adhesion of human osteoblasts on root-end filling materials. J Endod 2000, 26:404-406.

53. Andresson JO, Munksgaard EC, Frecebo L, Rud J: Periodontal tissue regeneration including cementogenesis adjacent to dentin-bonded retrograde composite fillings in humans. J Endod 1993, 19:151-153.

54. Selimović-Dragaš M, Huseinbegović A, Kobašlija S, Hatibović-Kofman Š: A comparion of the in vitro cytotoxicity of conventional and resin modified glass ionomer cements. Bosn J Basic Med Sci 2012, 12:273-278.

55. Schweikl H, Spagnuolo G, Schmalz G: Genetic and cellular toxicology of dental resin monomers. J Dent Res 2006, 85:870-877.

56. Goldberg $M:$ In vitro and in vivo studies on the toxicity of dental resin components: a review. Clin Oral Investig 2008, 12:1-8.

\section{Submit your next manuscript to BioMed Central and take full advantage of:}

- Convenient online submission

- Thorough peer review

- No space constraints or color figure charges

- Immediate publication on acceptance

- Inclusion in PubMed, CAS, Scopus and Google Scholar

- Research which is freely available for redistribution 